\title{
Novel supramolecular affinity materials based on $(-)$-isosteviol as molecular templates
}

\author{
Christina Lohoelter, Malte Brutschy, Daniel Lubczyk \\ and Siegfried R. Waldvogel ${ }^{*}$
}

\author{
Full Research Paper

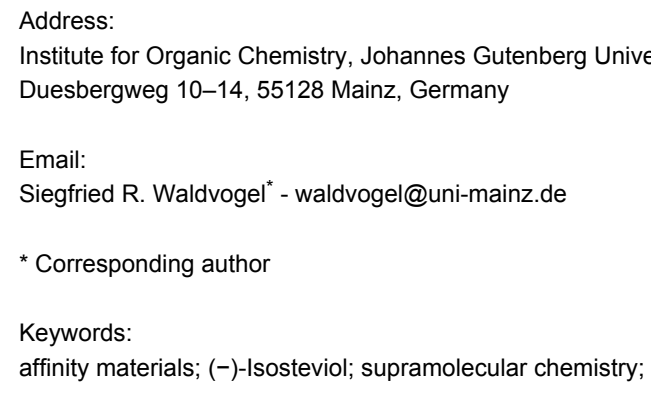

Open Access

\begin{abstract}
The readily available ex-chiral-pool building block (-)-isosteviol was combined with the $C_{3}$-symmetric platforms hexahydroxytriphenylene and hexaaminotriptycene providing large and rigid molecular architectures. Because of the persistent cavities these scaffolds are very potent supramolecular affinity materials for head space analysis by quartz crystal microbalances. The scaffolds serve in particular as templates for tracing air-borne arenes at low concentration. The affinities of the synthesized materials towards different air-borne arenes were determined by $200 \mathrm{MHz}$ quartz crystal microbalances.
\end{abstract}

\section{Introduction}

Divalent building blocks with a well-defined geometry play a significant role in the construction of highly potent supramolecular structures [1-5]. The rigid nature of such architectures limits the degrees of freedom and guarantees a good preorganization [1,2,6-10]. Particular interest was given to $C_{3}$-symmetric structures, serving e.g. as templates in asymmetric catalysis or molecular recognition [11-14].

A specific but potent subclass of such $C_{3}$-symmetric architectures is represented by triphenylene ketals [15]. They have found significant application as receptors and chemical sensors in the detection of aromatic compounds [16-20]. Thus, the first artificial receptor for caffeine had been established [21,22]. The introduction of chiral information onto a supramolecular entity gave rise for enantiofacial differentiation of a single substrate $[23,24]$. Due to the concave arrangement of both functional groups, exhibiting a distance of the two carbonyl carbon atoms of about $7 \AA$, naturally occurring diterpene (-)-isosteviol 1 [25] came into focus as building block for the construction of such receptor geometries (Figure 1) [26].

(-)-Isosteviol 1 can be easily obtained on large scale by acidic treatment of stevioside [27,28]. This stevioside is a commercially available natural sweetener which is isolated from stevia 


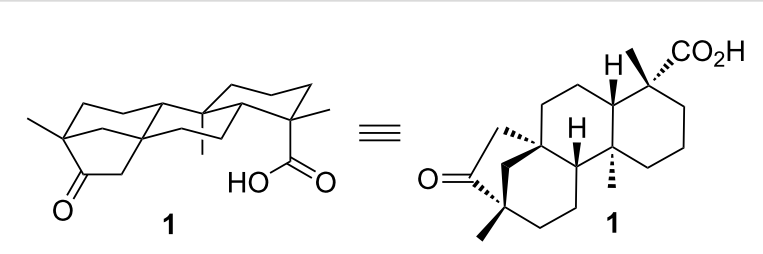

Figure 1: Unique structural features of (-)-isosteviol.

rebaudiana by alcoholic extraction $[29,30]$. In addition to their cytotoxic activities [31-34], compounds based on (-)-isosteviol have found application in various fields of synthetic chemistry [35], including the construction of tweezer-like supramolecular transporters for amino acids [36], chiral organocatalysts in aldol reactions [37], or the complex formation with aromatic compounds [38,39], Within in a nine-step synthesis triphenylene ketals based on (-)-isosteviol were prepared [40]. Receptor structures 2 equipped with amino or sulfonylamido functionalities were obtained (Figure 2).

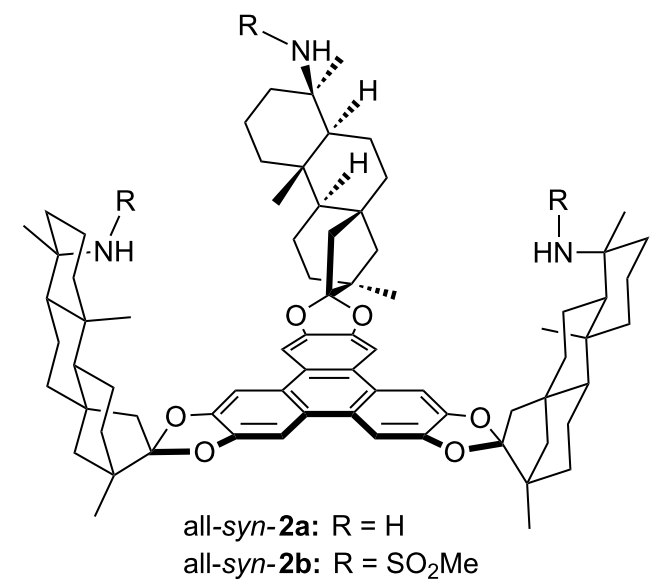

Figure 2: Triphenylene ketal based on (-)-isosteviol.

In addition to triphenylene ketals, triptycene-based structures also exhibit the geometrical requirements for the formation of $C_{3}$-symmetric architectures with extended cavities. Due to their structural features, triptycenes have found widespread application in organic synthesis: Ranging from polymer sciences [41], materials for gas storage [42-50], (organo)catalysis [51,52], molecular machinery $[53,54]$ and supramolecular host-guest chemistry $[55,56]$. With an angle of $120^{\circ}$ between its aromatic moieties, it exhibits a rigid geometry with a defined alignment of functional groups (Figure 3, left). Next to classical convergent-concave structures, architectures with a divergent-concave arrangement of functionalities can be obtained upon installation of building blocks with a linear geometry (Figure 3, right).

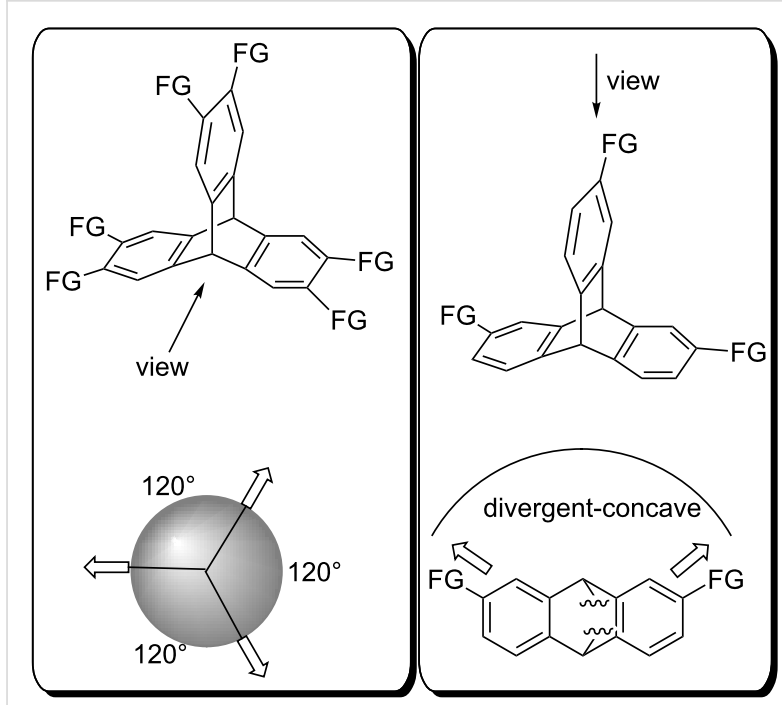

Figure 3: Structural features of triptycene derivatives.

Here, the functionalization of (-)-isosteviol-based triphenylene ketal all-syn-2a as well as the combination of (-)-isosteviol with the triptycene platform is reported. The application of these novel architectures as supramolecular affinity materials was studied.

The investigations of these possible affinity materials were carried out with $200 \mathrm{MHz}$ high fundamental frequency quartz crystal microbalances (HFF-QCMs) via gravimetric sensing of the adsorbed analytes. The advantage of HFF-QCMs is the low detection limit and the fast, highly reproducible and easy to apply electro spray protocol for the coating of such devices [5759]. Almost all organic materials which show at least a certain solubility in tetrahydrofuran or other volatile organic solvents allow application of this versatile coating protocol. For such studies only small amounts of affinity material in the sub mg-range are required.

The frequency shifts of the coated QCMs were determined for different analyte concentrations. Subsequently, the constants of the Langmuir isotherm are obtained by fitting the frequency shifts over concentration. The affinity of an affinity material to an analyte is calculated by multiplication of these constants. Details about the experimental setup and the determination of the affinities are given in Supporting Information File 1.

\section{Results and Discussion Triphenylene ketals}

The high hydrogen bonding donor capability of sulfonamides made this class of functional groups highly attractive for supramolecular affinity materials [60]. The installation of larger substituents at the sulfonyl moiety should provide suitable prop- 
erties for the processing on the quartz crystal microbalances. Based on the reported triamine all-syn-2a [40], 2a was brought to reaction with para-toluenesulfonyl chloride in order to equip the receptor scaffold with sulfonamide binding sites (Scheme 1).

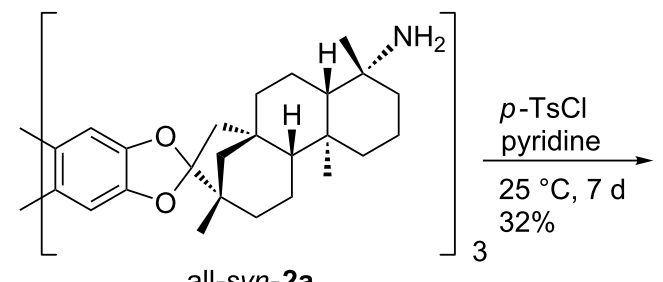

all-syn-2a

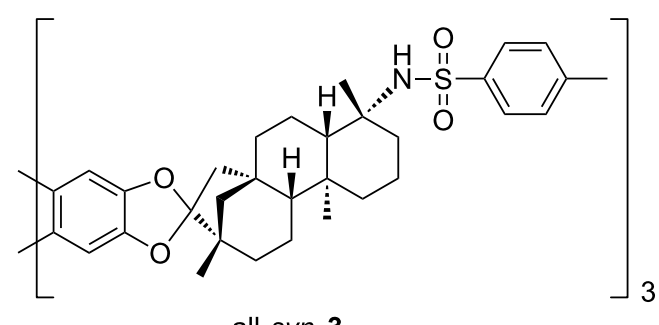

all-syn-3

Scheme 1: Functionalization of triphenylene ketal 2a.

The reaction proceeds with a moderate yield of $32 \%$ under very mild reaction conditions. The high steric demand in vicinity of the amino functions requires these prolonged reaction times. Unfortunately, more drastic reaction conditions lead to degradation of the substrate.

\section{Triptycenes}

Recently, the synthesis of hexaammoniumtriptycene hexachloride 4 (Figure 4) was reported by Mastalerz et al. [61]. Further, $(-)$-isosteviol and its esters can be converted into the corresponding 1,2-diketones 5a-c via Riley oxidation [62-66]. The linkage of the two building blocks by condensation reaction of the keto with the amino functionalities presents a promising route for the construction of novel $(-)$-isosteviol-based $C_{3}$-symmetric scaffolds.

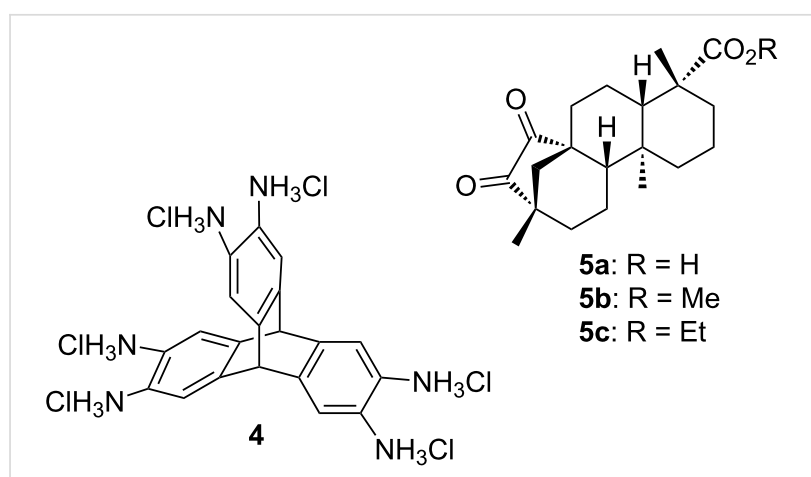

Figure 4: Hexaammoniumtriptycene hexachloride 4 and 15-oxoderivatives 5 a-c of (-)-isosteviol.

For the elaboration of optimal condensation conditions to form quinoxalines and to obtain model compounds representing subunits for the triptycene architectures $o$-phenylenediamines were employed (Scheme 2). It turned out that $\mathbf{5 b}$ forms the corresponding quinoxaline derivatives $\mathbf{6}$ and 7 in acceptable yields of $41 \%$ and $60 \%$, respectively, when refluxing in glacial acetic acid.

The established reaction conditions failed on the $C_{3}$-symmetric platform due to the poor solubility of the starting materials. Switching to a protocol with sodium acetate as additional base and operation in a sealed tube provided a satisfactory yield of $\mathbf{8}$ (Scheme 3) [61]. By molecular modelling the structural features can be visualized (Figure 5). A relatively closed $C_{3}$-symmetric cleft is formed by all-syn-8 (Figure 5a), whereas the less symmetric anti,anti,syn-8 (Figure 5b) provides an open side to access the concave regime.

As anticipated, two stereoisomers are formed in this condensation reaction of $\mathbf{5 b}$ with $\mathbf{4}$. After separation via column chromatography, these products were identified as the all-syn- and anti,anti,syn-isomers of the desired product $\mathbf{8}$, which were obtained in a total yield of $59 \%$. Due to very similar polarity of both isomers, the separation turned out to be tedious. Thus, pure anti,anti,syn-8 and all-syn-8 were isolated in yields of only $25 \%$ and $3 \%$, respectively, with the remaining $31 \%$ as mixture of isomers. In order to facilitate the separation of isomers the ester moiety of (-)-isosteviol was converted into nitrobenzylic esters.

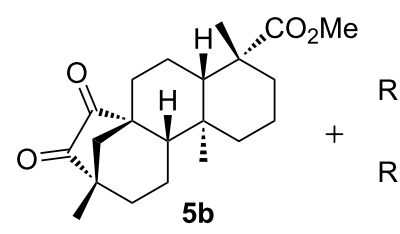<smiles>[R]c1cc(N)c(N)cc1[R]</smiles>
$\underset{\text { reflux, } 4 \mathrm{~h}}{\mathrm{AcOH}}$

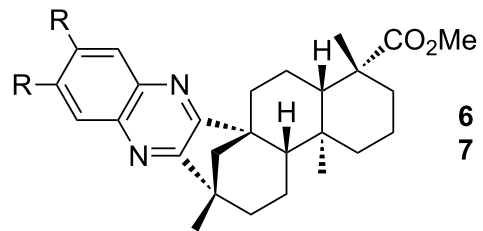



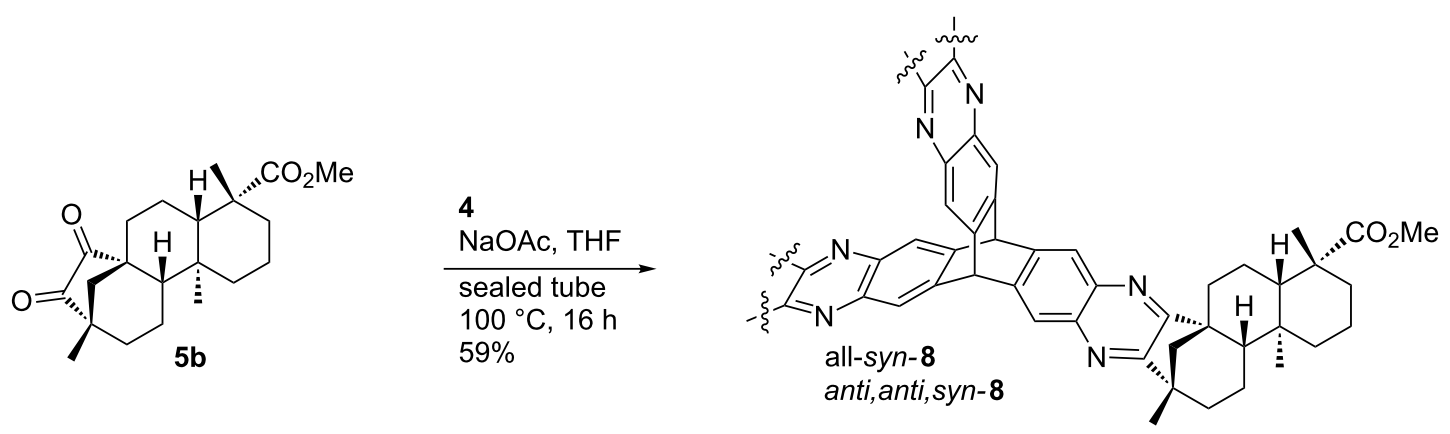

Scheme 3: Condensation of $\mathbf{5 b}$ with hexaammoniumtriptycene hexachloride.

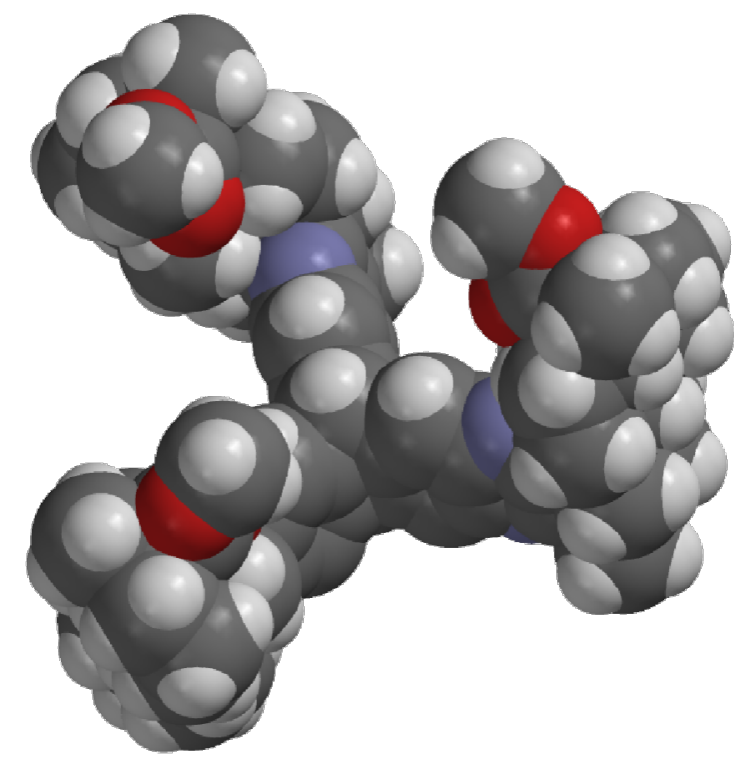

a)

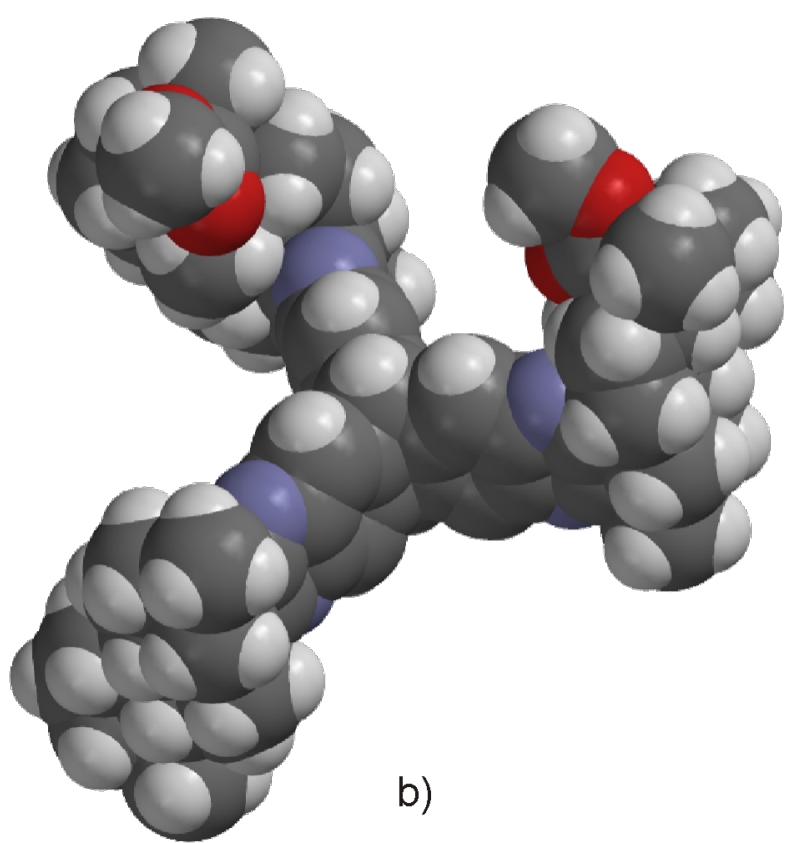

Figure 5: Molecular modelling structures (Spartan '08 V1.0.0) of (a) all-syn-8 and (b) anti,anti,syn-8.

The highly polar nitro groups at the periphery of the resulting triptycene isomers should provide the desired difference in polarity. Another feature of the employment of benzyl derivatives is the facile cleavage under reductive conditions representing a versatile precursor for further modifications. Starting from (-)-isosteviol $\mathbf{1}$, there are two ways of obtaining the diketo building blocks 10 and 11, bearing a dinitrobenzylic (DNB) and a $p$-nitrobenzylic (PNB) ester moiety, respectively (Scheme 4).

Following path A, (-)-isosteviol can be oxidized under Riley conditions (Table 1, reaction conditions a: selenium dioxide/ xylene) $[62,63]$ to give the corresponding diketone 9 [66]. Subsequent esterification with 3,5-dinitrobenzylic chloride under basic conditions (Table 1, reaction conditions $\mathbf{b}$ for $\mathrm{R}=\mathrm{DNB}$ ) [67] proceeds with a yield of $57 \%$ and leads to the formation of 10 with an overall yield of $46 \%$. Alternatively, protection of the carboxylic acid function of (-)-isosteviol can be carried out first (path B), yielding dinitrobenzyl ester 12. Subsequent Riley-oxidation renders the desired product $\mathbf{1 0}$ in an overall yield of $48 \%$. Since path A and path B both proceed with almost identical yields, either pathway is suitable for the preparation of such protected 1,2-diketones. Apart from applying 3,5-dinitrobenzyl chloride in the reaction sequence, the conversion of the carboxylic acids $\mathbf{1}$ and 9 with 4-nitrobenzyl (PNB) chloride was carried out (Scheme 4). Again, both paths $\mathbf{A}$ and $\mathbf{B}$ lead to the formation of the desired PNB protected diketone 11. Esterification was achieved by reaction with 4-nitrobenzyl chloride and cesium carbonate in DMF (Table 1, reaction conditions $\mathbf{b}$ for $\mathrm{R}=\mathrm{PNB}$ ) [68]. Both sequences $\mathbf{A}$ and $\mathbf{B}$ proceed with similar overall yields as well, rendering 11 in 54\% and 57\%, respectively. Upon employing 4-nitrobenzyl chloride, both reaction paths result in slightly 


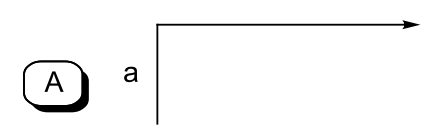

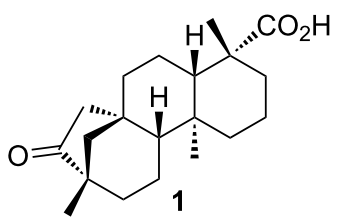

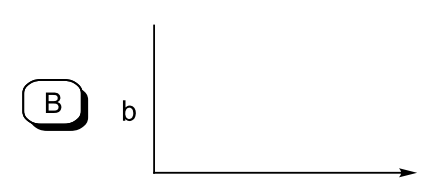

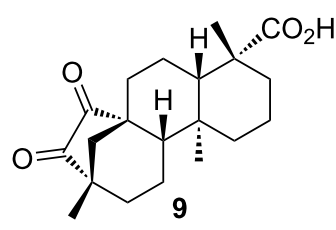<smiles>CCC</smiles>

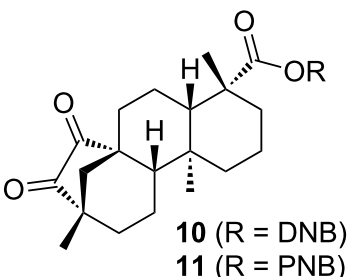

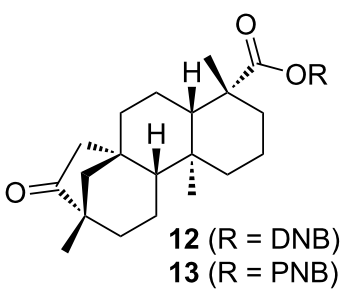

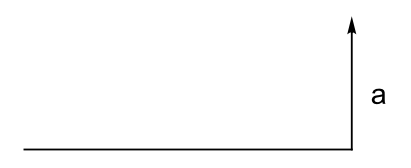

$12(R=D N B)$
$13(R=P N B)$

Scheme 4: Synthesis of nitrobenzylic ester derivatives 10 and 11, starting from (-)-isosteviol 1.

Table 1: Oxidation and esterification sequence of 1

\begin{tabular}{|c|c|c|c|}
\hline$R=$ & Reaction conditions & Yield & Overall yield $a+b$ \\
\hline \multirow{4}{*}{ } & a: $\mathrm{SeO}_{2}$, xylenes, $145^{\circ} \mathrm{C}, 2 \mathrm{~d}$ & $\begin{array}{l}\text { 9: } 80 \% \\
10: 78 \%\end{array}$ & Path A: $46 \%$ \\
\hline & b: 3,5-dinitrobenzyl chloride, $\mathrm{NEt}_{3}, \mathrm{DMF}, 25^{\circ} \mathrm{C}, 16 \mathrm{~h}$ & $\begin{array}{l}\text { 12: } 61 \% \\
10: 57 \%\end{array}$ & Path B: $48 \%$ \\
\hline & a: $\mathrm{SeO}_{2}$, xylenes, $145^{\circ} \mathrm{C}, 2 \mathrm{~d}$ & $\begin{array}{l}\text { 9: } 80 \% \\
11: 74 \%\end{array}$ & Path A: $54 \%$ \\
\hline & b: 4-nitrobenzyl chloride, $\mathrm{Cs}_{2} \mathrm{CO}_{3}, \mathrm{DMF}, 25^{\circ} \mathrm{C}, 5 \mathrm{~h}$ & $\begin{array}{l}\text { 13: } 77 \% \\
\text { 11: } 68 \%\end{array}$ & Path B: $57 \%$ \\
\hline
\end{tabular}

higher yields than the analogous reactions with 3,5-dinitrobenzyl chloride. Diketones $\mathbf{1 0}$ and $\mathbf{1 1}$ were then brought to condensation with hexaammoniumtriptycene hexachloride $\mathbf{4}$, following the protocol mentioned above (Scheme 5). Reaction of the 3,5-dinitrobenzyl ester $\mathbf{1 0}$ with $\mathbf{4}$ renders the corresponding triptycene structure $\mathbf{1 4}$ as a mixture of isomers in a good total yield of $86 \%$. However, the impact of the nitro groups at the periphery of the molecule on the polarity of the isomers was far less than anticipated. After twofold column chromatography, the anti,anti,syn-isomer was isolated in a yield of $48 \%$ while the all-syn-isomer was obtained in $17 \%$ yield, again leaving the rest as a mixture of isomers.

Reaction of 4-nitrobenzyl ester $\mathbf{1 1}$ with $\mathbf{4}$ leads to the formation of the corresponding triptycenes anti,anti,syn-15 and all-syn-15 in an excellent total yield of $95 \%$. Separation of the isomers results in the isolation of $34 \%$ of the anti,anti,syn-isomer and $12 \%$ of the all-syn-isomer, leaving the remaining $49 \%$ as a mixture of isomers.

The benzyl ester moiety of all-syn-15 was subsequently cleaved by hydrogenolysis using standard conditions (Scheme 6) [69]. The tricarboxylic acid all-syn-16 was isolated in almost quantitative yield. In this protocol the heterogeneous catalyst did not affect the quinoxaline moieties by over-reduction.

With this versatile precursor all-syn-16 in hands and the need for organic materials with pronounced cavities as potent affinity materials we envisioned the synthesis of a capsule-type architecture. Therefore, all-syn-16 was $O$-alkylated by treatment with 


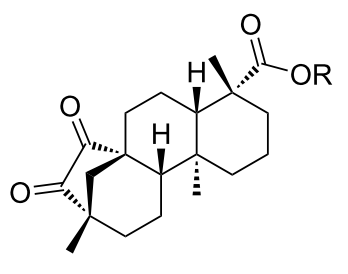

\section{4}

$\mathrm{NaOAc}, \mathrm{THF}$

sealed tube $100^{\circ} \mathrm{C}, 16 \mathrm{~h}$

$10(\mathrm{R}=\mathrm{DNB}$<smiles>CCc1cc([N+](=O)[O-])cc([N+](=O)[O-])c1</smiles><smiles>[R]=[Pb]CCc1ccc([N+](=O)[O-])cc1</smiles>

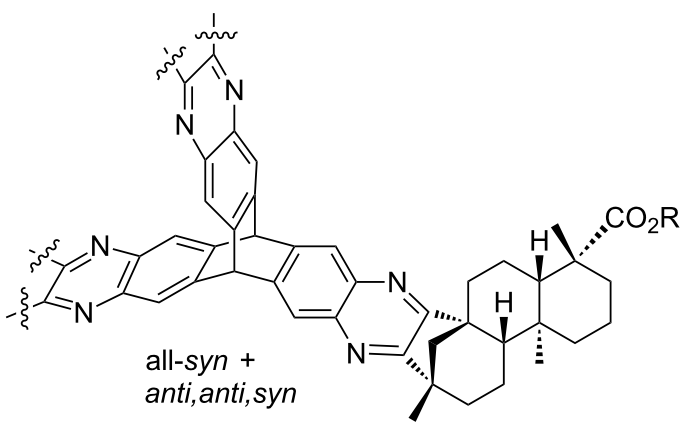

$14(\mathrm{R}=\mathrm{DNB}, 86 \%)$

$15(\mathrm{R}=\mathrm{PNB}, 95 \%)$

Scheme 5: Condensation of the nitrobenzyl esters 10 and 11 with hexaammoniumtriptycene hexachloride 4.

\section{all-syn-15}

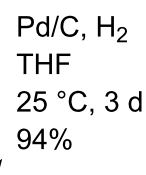

$\mathrm{Pd} / \mathrm{C}, \mathrm{H}_{2}$

THF

$25^{\circ} \mathrm{C}, 3 \mathrm{~d}$

$94 \%$

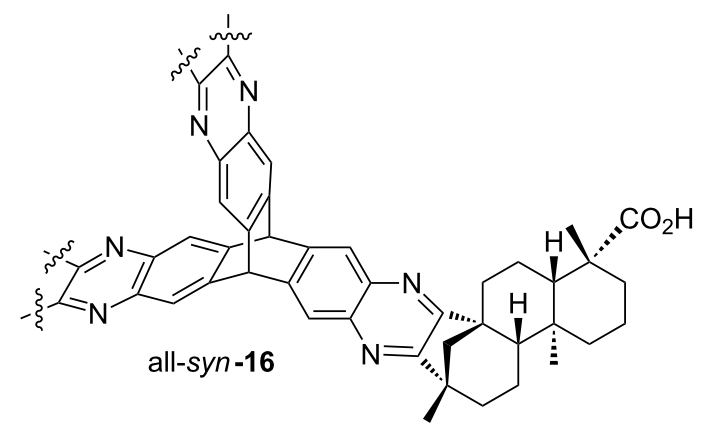

Scheme 6: Hydrogenolysis to tricarboxylic acid all-syn-16.

5-bromo-1-pentene using standard conditions [70] to yield the corresponding triptycene derivative all-syn-17 (Scheme 7). Alkylation proceeded with a moderate yield of $31 \%$. Equipped with three terminal alkenes all-syn-17 seems to be a suitable precursor for subsequent olefin metathesis to form a capsulelike structure.

The structure of all-syn-17 was confirmed via X-ray analysis of a suitable single crystal. The molecular structure clearly reveals the spatial arrangement of the terminal alkene moieties. The side view of all-syn-17 (Figure 6b) unequivocally shows the cavity which is formed, its size ranging approximately to the quinoxaline-nitrogen atoms of the triptycene core which exhibit

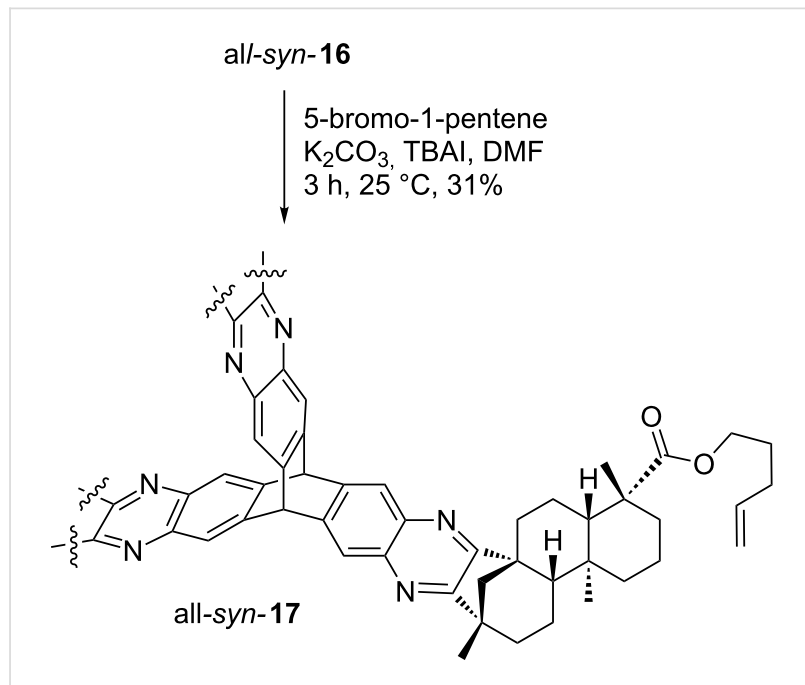

Scheme 7: Alkylation of all-syn-16 renders terminal alkene all-syn-17.

a mutual distance of $8.1 \AA, 8.8 \AA$ and $8.9 \AA$, whereas the carboxylic carbon atoms exhibit a distance of about $12 \AA$. The cavity of all-syn-17 is "roofed" by the alkyl chains of the (-)isosteviol units (Figure 6a), whose terminal carbon atoms show a mutual distance in the range of 4.2-5.2 .

Since the introduction of nitrobenzyl esters as protecting groups for the (-)-isosteviol carboxylic acid moiety obviously does not have an enhanced effect on the polarity of the two isomers and, as a consequence, the chromatographic separation procedure does not correlate with the nature of the ester substituent, the detour via protecting groups in the synthesis of alkylated triptycene 17 was subsequently avoided. Therefore, alkylated diketone $\mathbf{1 8}$ was synthesized, starting from (-)-isosteviol 


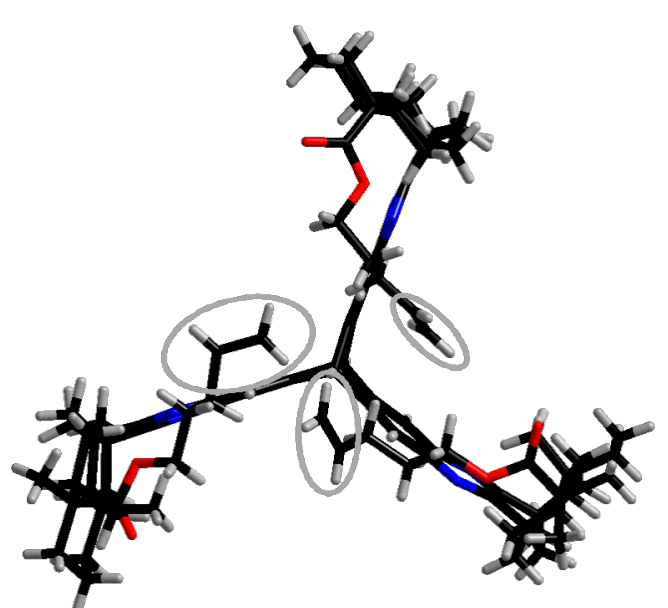

a)

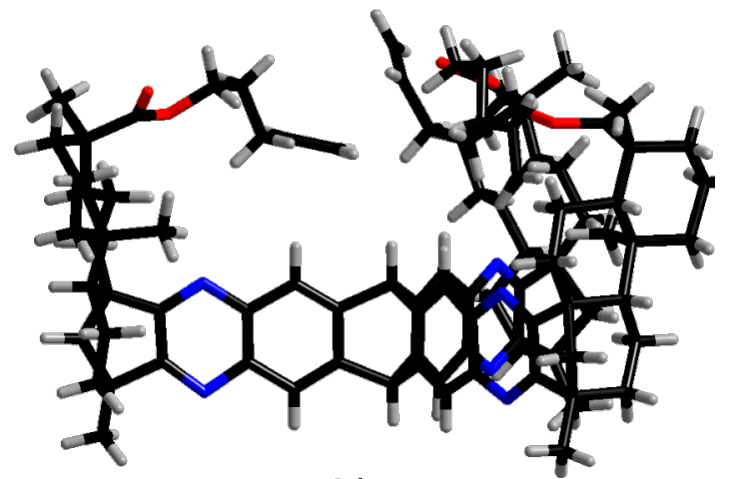

b)

Figure 6: (a) Top view on the molecular structure of all-syn-17 with the terminal alkene fragments labelled in grey; (b) side view of all-syn-17.

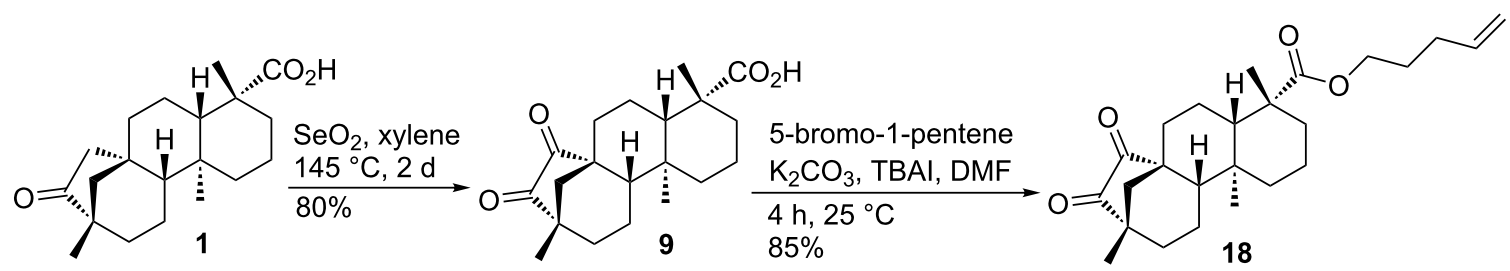

Scheme 8: Alkylation of (-)-isosteviol diketone 9 with 5-bromo-1-pentene.

(Scheme 8). Since alkenes are known to participate in Riley oxidations as well, rendering allylic alcohols, there is only one route to $\mathbf{1 8}$. After Riley oxidation of $\mathbf{1}$, alkylation was carried out under the same reaction conditions as before, providing the desired product in a yield of $85 \%$ [70].

18 was then brought to reaction with hexaammoniumtriptycene hexachloride 4 (Scheme 9). The corresponding all-syn- and anti,anti,syn-isomers of $\mathbf{1 7}$ were obtained in an overall yield of $67 \%$.

After twofold column chromatography, complete separation of the isomers was achieved. The anti,anti,syn-derivative was isolated in a yield of $44 \%$ whereas the all-syn-derivative was obtained in 23\% yield. The molecular structure of all-syn-17 depicted in Figure 6 provides the rationale for the ameliorated separation of the isomers. The protection of one side with alkenyl esters blocks the access of the quinoxaline moieties from one side. The all-syn derivatives will show a better interaction with the stationary phase. The combination of entire isomer separation and shortcut in the reaction sequence (three steps instead of five, starting from (-)-isosteviol) makes this a highly attractive route for the construction of the desired
18

$\mid \begin{aligned} & \mathbf{4} \\ & \text { NaOAC, THF } \\ & \text { sealed tube } \\ & 100{ }^{\circ} \mathrm{C}, 16 \mathrm{~h} \\ & 67 \%\end{aligned}$

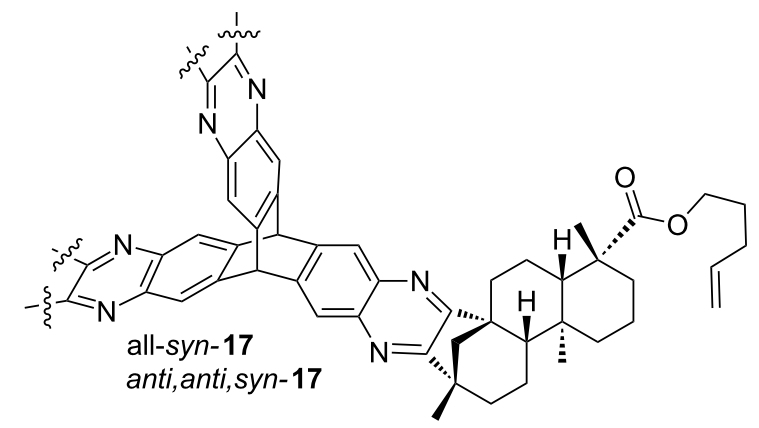

Scheme 9: Direct synthesis of alkylated triptycene 17 by condensation of $\mathbf{1 8}$ with hexaammoniumtriptycene hexachloride 4 .

triptycene derivatives. All-syn-17 was then brought to reaction in an olefin metathesis (Scheme 10), employing the $2^{\text {nd }}$ generation Grubbs catalyst in refluxing dichloromethane. 

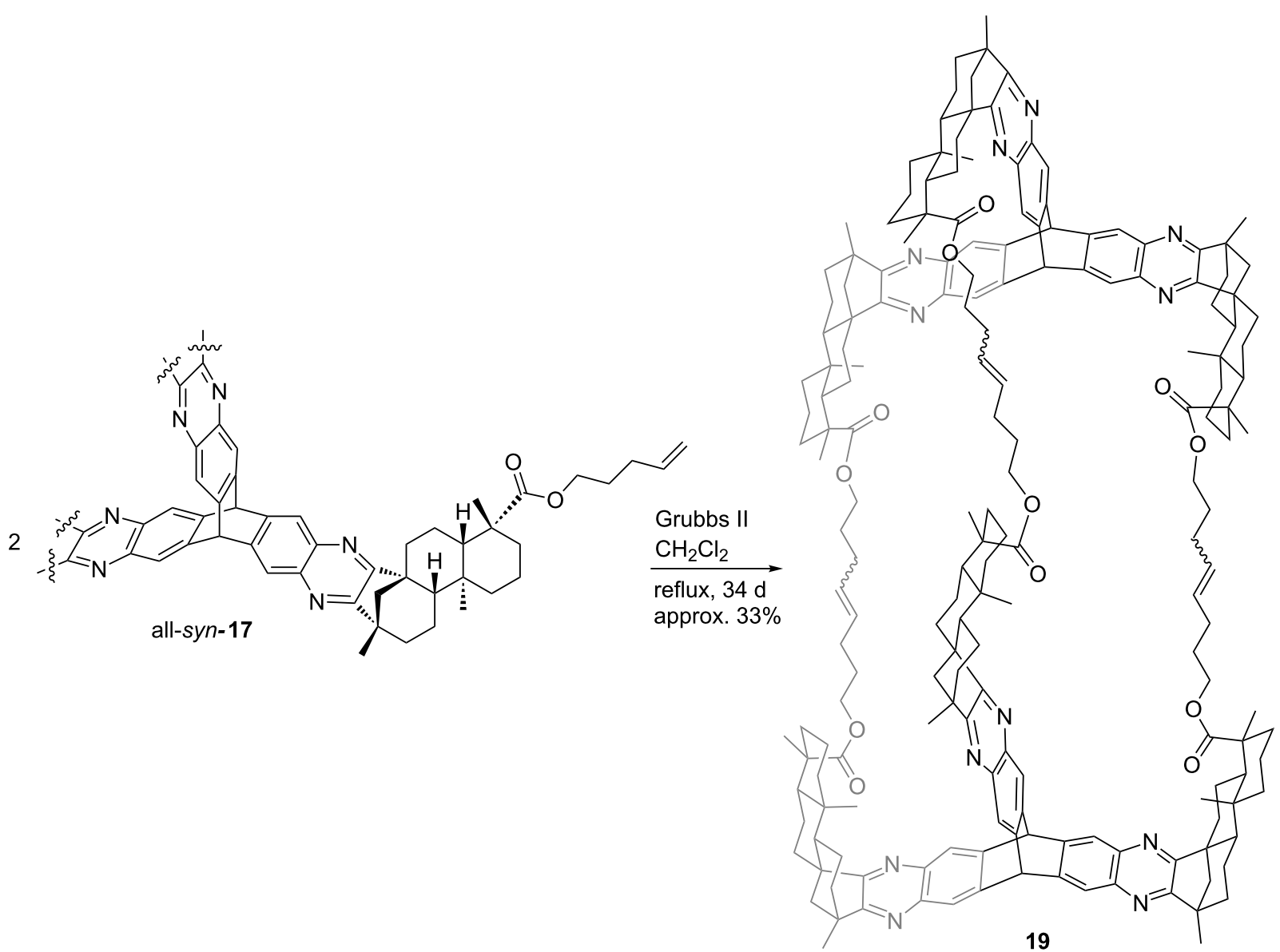

Scheme 10: Olefin metathesis of all-syn-17.

Even after prolonged reaction times, complete conversion of the starting material could not be achieved. However, the formation of a sole product was observed. Upon chromatographic separation, the product was obtained, exhibiting a molecular weight corresponding to the cage-like structure 19. Comparison of according sections from the carbon NMR spectra of starting material and product shows that the signal which corresponds to the terminal carbon atom in the starting material (Figure 7, grey) is not existent in the product spectrum. Furthermore, a new set of signals (Figure 7, green) can be seen in the product spectrum which show typical shifts of 1,2-disubstituted alkenes.

Since the obtained analytical data strongly indicate the existence of cage compound 19, molecular modelling calculations (Figure 8, MacroModel 9.3.5) indicate a "collapsed" structure in which the triptycene units are twisted by $60^{\circ}$ and approaching each other, prohibiting the formation of significant voids for intercalation of analytes.

\section{Results of the gravimetric measurements with HFF-QCMs}

Triphenylene ketal 3 and the triptycene derivatives 8, 14, 15, 17, 19 and the model compound 7 were subjected to QCM measurements in order to evaluate their properties to serve as affinity materials in the tracing of volatile aromatic compounds. For this purpose, a collection of chemically related aromatic analytes were screened. The analytes range from benzene to pseudocumene, exhibiting similar electronic properties but differing in their size. This allows a probing of cavity size of the individual affinity materials.

Triptycene based material anti,anti,syn-8 shows the highest affinity towards aromatic analytes, which can be rationalized with a more facile access of the analyte to the void created by the anti,anti,syn-isomer (Figure 9).

This remarkable effect can already be observed when plotting the primary data (Figure 10). 

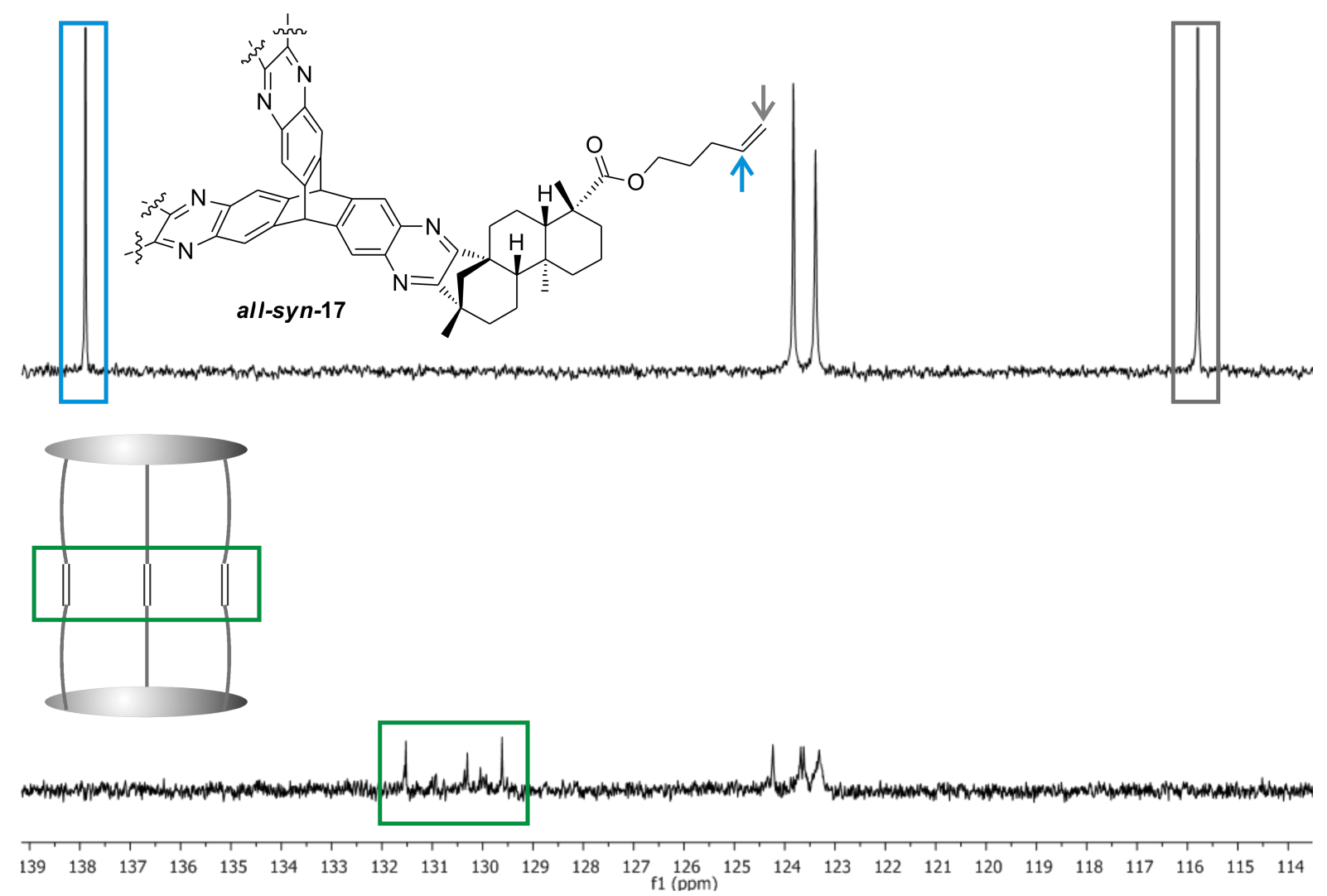

Figure 7: Extracts of the ${ }^{13} \mathrm{C}$ NMR spectra of starting material and product.

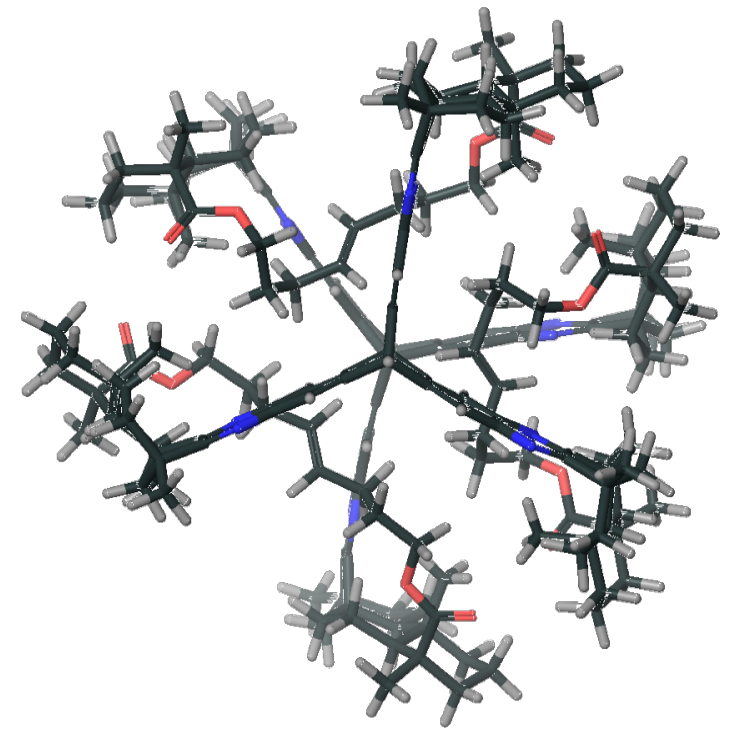

a)

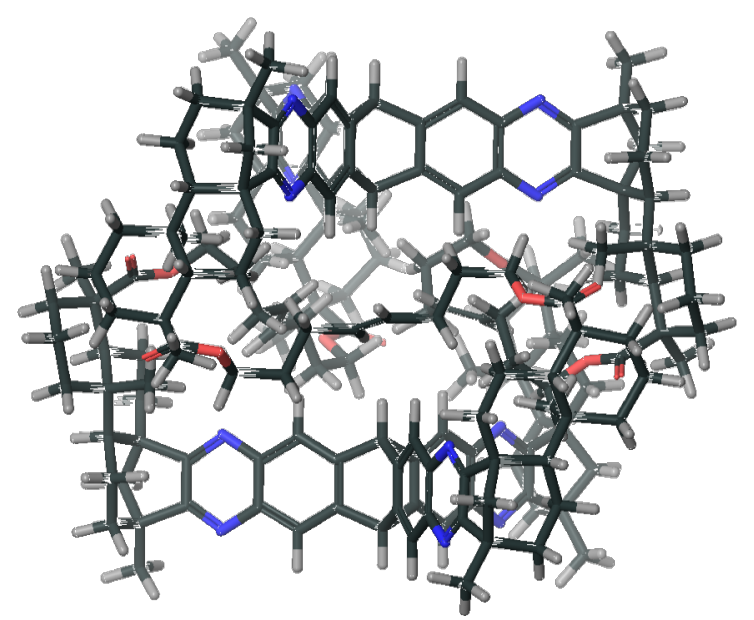

b) 


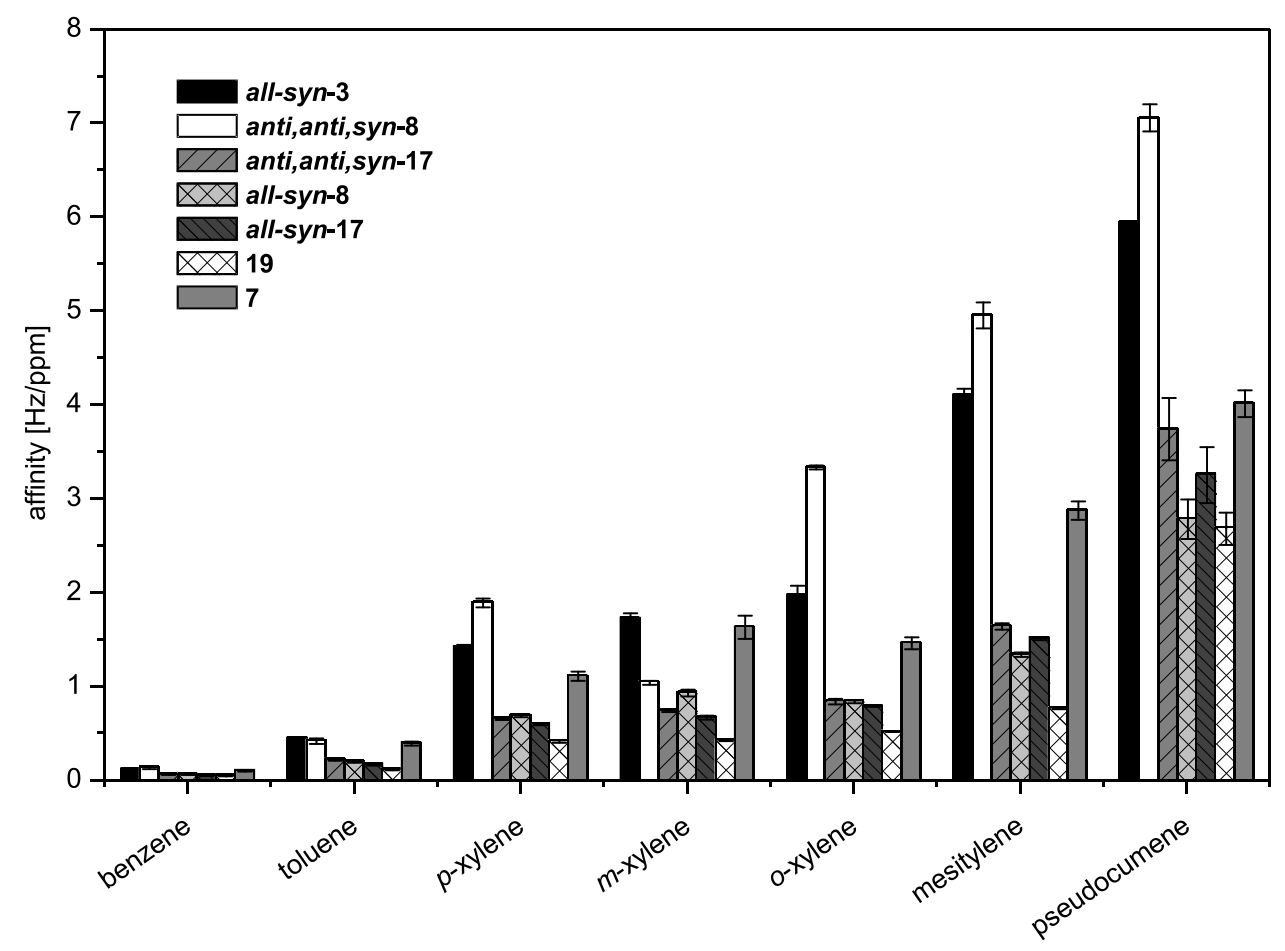

Figure 9: Screening of aromatic analytes with affinity materials 3, 7, 8, 17 and 19.

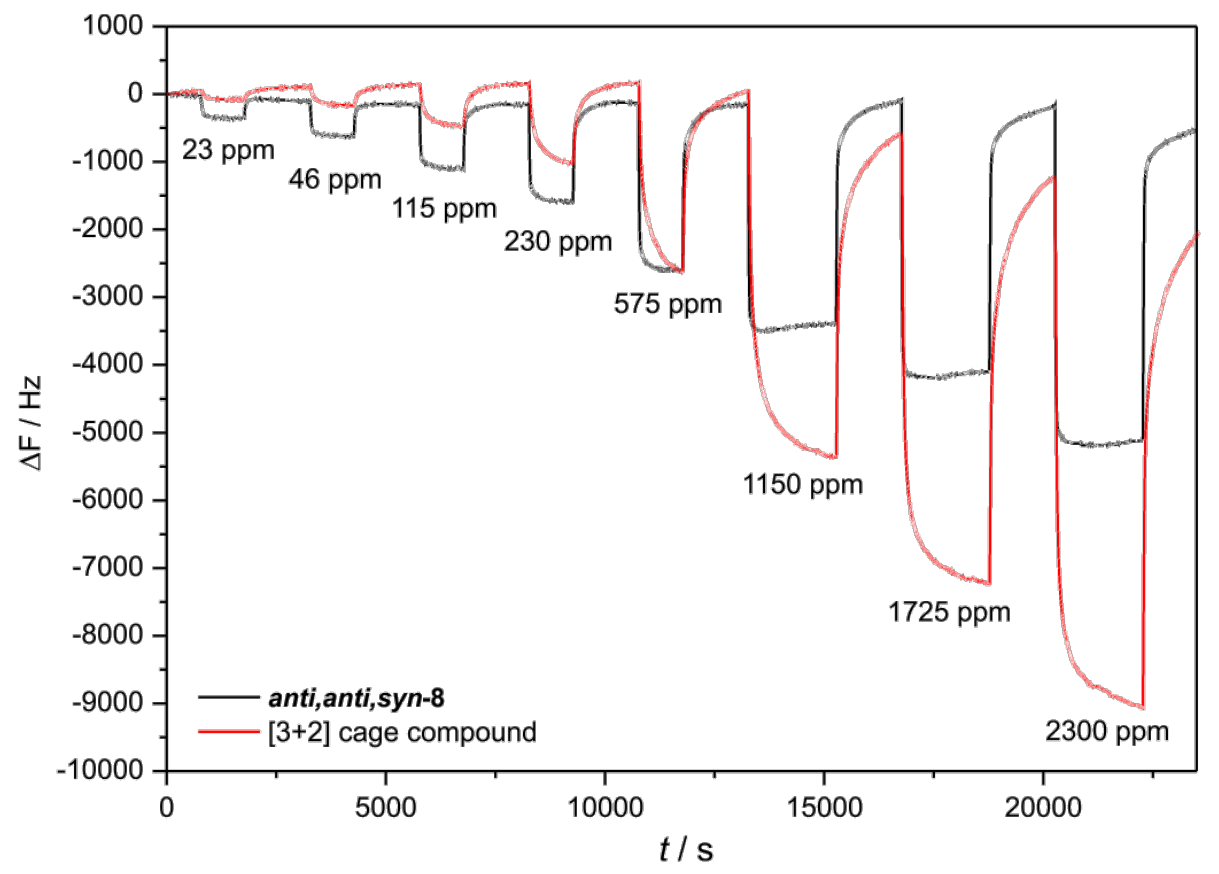

Figure 10: Primary data of anti,anti,syn-8 and a [3 + 2] cage compound (increasing pseudocumene concentrations and recovery times between each step, for details see Supporting Information File 1). 
For comparison, we included the primary data of an organic cage compound (for structure see Supporting Information File 1) which was published recently [71]. At small concentrations which are relevant for tracing, anti,anti,syn-8 is creating unusual large signals which indicates a high affinity of the material for this analyte. For high concentrations, other materials like the $[3+2]$ cage compound get ahead in means of signal depth, indicating more places for adsorption on/in the film. This behavior of anti,anti,syn-8 is exclusively observed for the aromatic analytes. Our triptycene-based cage compound 19 exhibits only moderate affinities, which is in accordance with the calculated collapsed structure (Figure 8).

For protic analytes, anti,anti,syn-8 is comparable or even inferior to other triptycene based materials (Figure 11). Therefore, anti,anti,syn-8 is a very promising substance for the application as affinity material in a sensor array for the tracing of air-borne aromatic compounds at high dilution. Besides anti,anti,syn-8, the triphenylene based architecture all-syn-3 also exhibits excellent affinities towards the aromatic analytes as well as very inferior affinities to protic analytes (Figure 11).

The affinities of triptycene derivatives with different protecting groups on the carboxylic acid function to protic analytes were then compared (Figure 11). While the adsorption of aromatic analytes is dominated by the cavity size, the nature of the protection group dominates the adsorption of the protic analytes via hydrogen bonding [72]. A clear dependency on the number of nitro groups in the molecule, ascending from $\mathbf{8}$ with no nitro group to $\mathbf{1 4}$ with six nitro groups per molecule, is observed, indicating a strong influence of hydrogen bonding interactions between analyte and affinity material.

\section{Conclusion}

Architectures based on triptycenes and (-)-isosteviol create molecular voids which can accommodate guest molecules. These molecular templates are the basis for powerful affinity materials of quartz crystal microbalances (QCM). In particular, the combination of 15-oxoisosteviol methyl ester with hexaaminotriptycene provides upon condensation reaction the statistically prone anti,anti,syn-derivative which shows unique properties as affinity material in QCM studies with aromatic analytes. Although this affinity material exhibits moderate performance at high analyte concentrations unusual strong signals are found at low concentrations of the analytes. This powerful and unique performance in the low ppm range is an essential prerequisite for latter tracing applications, e.g. gravimetric sensing. This superior property is attributed to well accessible molecular voids. As soon as such structures are allowed to collapse the outstanding affinity is not observed anymore.

\section{Experimental}

For preparation and characterization of the compounds, see Supporting Information File 1.

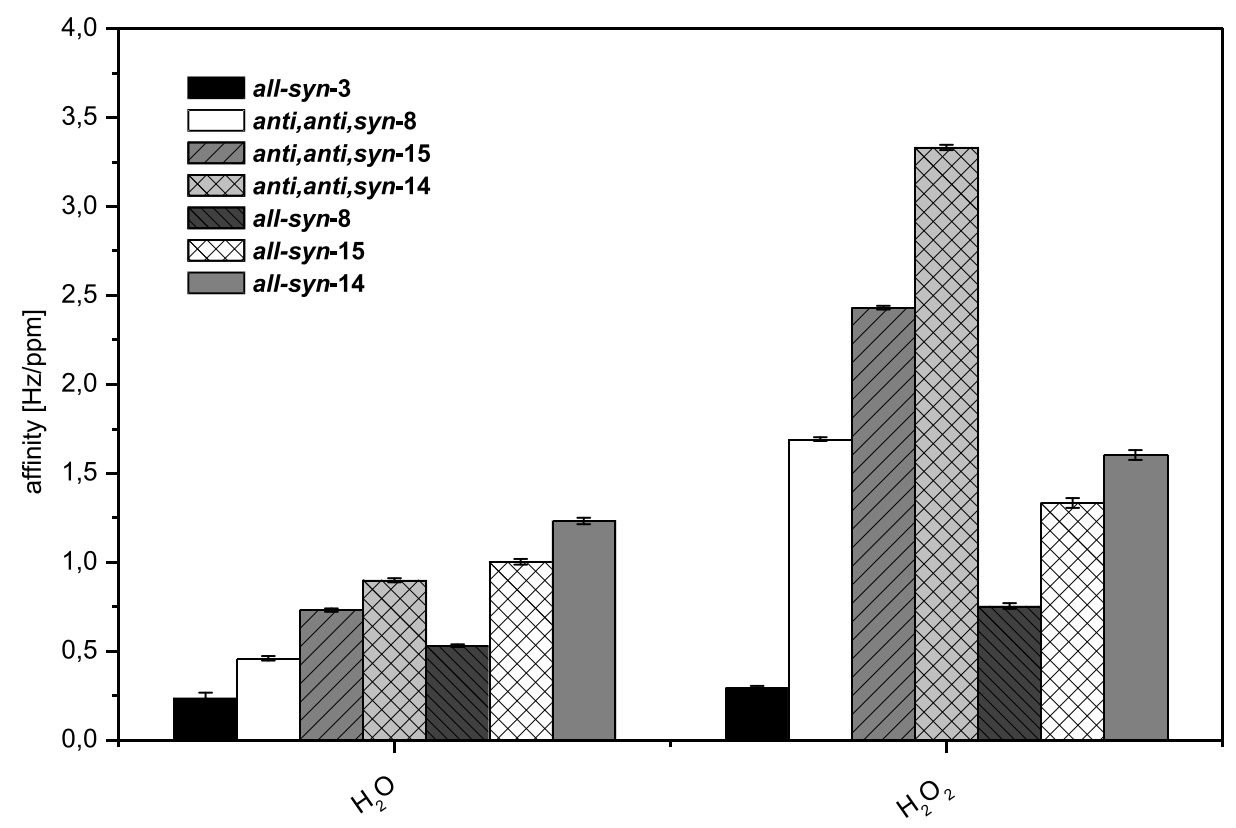

Figure 11: Screening of protic analytes with affinity materials 3, 8, 14 and 15 . 


\section{Supporting Information}

\section{Supporting Information File 1}

Characterization data, spectra of synthesized compounds,

QCM set up, and QCM screening details.

[http://www.beilstein-journals.org/bjoc/content/

supplementary/1860-5397-9-317-S1.pdf]

\section{Acknowledgements}

Funding by the SFB 624 is highly appreciated. The authors are in particular thankful to C. Siering who carried out the molecular modelling calculations.

\section{References}

1. Steed, J. W.; Turner, D. R.; Wallace, K. J. Core Concepts in Supramolecular Chemistry and Nanochemistry, 1st ed.; John Wiley \& Sons: Chichester, 2007.

2. Steed, J. W.; Atwood, J. L. Supramolecular Chemistry, 2nd ed.; John Wiley \& Sons: Chichester, 2009.

3. Lehn, J.-M. Supramolecular Chemistry. Concepts and Perspectives; VCH: Weinheim, 1995.

4. Kim, J.; McHugh, S. K.; Swager, T. M. Macromolecules 1999, 32, 1500-1507. doi:10.1021/ma981774r

5. Weilandt, T.; Troff, R. W.; Saxell, H.; Rissanen, K.; Schalley, C. A. Inorg. Chem. 2008, 47, 7588-7598. doi:10.1021/ic800334k

6. Diederich, F.; Stang, P. J.; Tykwinski, R. R., Eds. Modern Supramolecular Chemistry. Strategies for Macrocycle Synthesis, 1st ed.; Wiley-VCH: Weinheim, 2008. doi:10.1002/9783527621484

7. Raatikainen, K.; Beyeh, N. K.; Rissanen, K. Chem.-Eur. J. 2010, 16, 14554-14564. doi:10.1002/chem.201001695

8. Cram, D. J. Science 1988, 240, 760-767. doi:10.1126/science. 3283937

9. Hou, Z.; Sunderland, C. J.; Nishio, T.; Raymond, K. N. J. Am. Chem. Soc. 1996, 118, 5148-5149. doi:10.1021/ja9600946

10. Fiedler, D.; Leung, D. H.; Bergman, R. G.; Raymond, K. N. Acc. Chem. Res. 2005, 38, 349-358. doi:10.1021/ar040152p

11. Moberg, C. Angew. Chem. 1998, 110, 260-281. doi:10.1002/(SICI)1521-3757(19980202)110:3<260::AID-ANGE260>3. 0.CO;2-6

Angew. Chem., Int. Ed. 1998, 37, 248-268. doi:10.1002/(SICI)1521-3773(19980216)37:3<248::AID-ANIE248>3.0. $\mathrm{CO} ; 2-5$

12. Moberg, C. Angew. Chem. 2006, 118, 4838-4840. doi:10.1002/ange.200601214 Angew. Chem., Int. Ed. 2006, 45, 4721-4723. doi:10.1002/anie.200601214

13. Rebek, J., Jr. Angew. Chem. 1990, 102, 261-272. doi:10.1002/ange.19901020306 Angew. Chem., Int. Ed. Engl. 1990, 29, 245-255. doi:10.1002/anie.199002451

14. Gibson, S. E.; Castaldi, M. P. Chem. Commun. 2006, 3045-3062. doi:10.1039/b602237e

15. Waldvogel, S. R.; Wartini, A. R.; Rasmussen, P. H.; Rebek, J., Jr. Tetrahedron Lett. 1999, 40, 3515-3518. doi:10.1016/S0040-4039(99)00545-6
16. Orghici, R.; Lützow, P.; Burgmeier, J.; Koch, J.; Heidrich, H.; Schade, W.; Welschoff, N.; Waldvogel, S. R. Sensors 2010, 10, 6788-6795. doi:10.3390/s100706788

17. Börner, S.; Orghici, R.; Waldvogel, S. R.; Willer, U.; Schade, W. Appl. Opt. 2009, 48, B183-B189. doi:10.1364/AO.48.00B183

18. Siering, C.; Kerschbaumer, H.; Nieger, M.; Waldvogel, S. R. Org. Lett. 2006, 8, 1471-1474. doi:10.1021/ol0603110

19. Bomkamp, M.; Siering, C.; Landrock, K.; Stephan, H.; Fröhlich, R.; Waldvogel, S. R. Chem.-Eur. J. 2007, 13, 3724-3732. doi:10.1002/chem.200601231

20. Siering, C.; Beermann, B.; Waldvogel, S. R. Supramol. Chem. 2006, 18, 23-27. doi:10.1080/10610270500310479

21. Waldvogel, S. R.; Fröhlich, R.; Schalley, C. A. Angew. Chem. 2000, 112, 2580-2583. doi:10.1002/1521-3757(20000717)112:14<2580::AID-ANGE2580>3.0. CO;2-D

Angew. Chem., Int. Ed. 2000, 39, 2472-2475. doi:10.1002/1521-3773(20000717)39:14<2472::AID-ANIE2472>3.0.CO ;2-F

22. Schopohl, M. C.; Faust, A.; Mirk, D.; Fröhlich, R.; Kataeva, O.; Waldvogel, S. R. Eur. J. Org. Chem. 2005, 2987-2999. doi:10.1002/ejoc.200500108

23. Schopohl, M. C.; Siering, C.; Kataeva, O.; Waldvogel, S. R. Angew. Chem. 2003, 115, 2724-2727. doi:10.1002/ange.200351102 Angew. Chem., Int. Ed. 2003, 42, 2620-2623. doi:10.1002/anie.200351102

24. Siering, C.; Grimme, S.; Waldvogel, S. R. Chem.-Eur. J. 2005, 11, 1877-1888. doi:10.1002/chem.200401002

25. Bridel, M.; Lavieille, R. B. Soc. Chim. Biol. 1931, 781-796.

26. Lohoelter, C. Supramolekulare Affinitätsmaterialien basierend auf (-)-Isosteviol. Ph.D. Thesis, Johannes Gutenberg-Universität, Mainz, Germany, 2013.

The synthetic work presented in this manuscript is part of the Ph.D. thesis.

27. Mosettig, E.; Nes, W. R. J. Org. Chem. 1955, 20, 884-899. doi:10.1021/jo01125a013

28. Roy, A.; Roberts, F. G.; Wilderman, P. R.; Zhou, K.; Peters, R. J.; Coates, R. M. J. Am. Chem. Soc. 2007, 129, 12453-12460. doi:10.1021/ja072447e

29. Mosettig, E.; Beglinger, U.; Dolder, F.; Lichti, H.; Quitt, P.; Waters, J. A J. Am. Chem. Soc. 1963, 85, 2305-2309. doi:10.1021/ja00898a025

30. Wood, H. B.; Allerton, R.; Diehl, H. W.; Fletcher, H. G. J. Org. Chem. 1955, 20, 875-883. doi:10.1021/jo01125a012

31. Wu, Y.; Dai, G.-F.; Yang, J.-H.; Zhang, Y.-X.; Zhu, Y.; Tao, J.-C. Bioorg. Med. Chem. Lett. 2009, 19, 1818-1821. doi:10.1016/j.bmcl.2008.12.101

32. Wu, Y.; Liu, C.-J.; Liu, X.; Dai, G.-F.; Do, J.-Y.; Tao, J.-C. Helv. Chim. Acta 2010, 93, 2052-2069. doi:10.1002/hlca.201000046

33. Lin, L.-H.; Lee, L.-W.; Sheu, S.-Y.; Lin, P.-Y. Chem. Pharm. Bull. 2004, 52, 1117-1122. doi:10.1248/cpb.52.1117

34. Chatsudthipong, V.; Muanprasat, C. Pharmacol. Ther. 2009, 121, 41-54. doi:10.1016/j.pharmthera.2008.09.007

35. Lohoelter, C.; Weckbecker, M.; Waldvogel, S. R. Eur. J. Org. Chem. 2013, 5539-5554. doi:10.1002/ejoc.201300447

36. Kataev, V. E.; Strobykina, I. Yu.; Militsina, O. I.; Korochkina, M. G.; Fedorova, O. V.; Ovchinnikova, I. G.; Valova, M. S.; Rusinov, G. L. Tetrahedron Lett. 2006, 47, 2137-2139. doi:10.1016/j.tetlet.2006.01.126 
37. An, Y.-J.; Zhang, Y.-X.; Wu, Y.; Liu, Z.-M.; Pi, C.; Tao, J.-C. Tetrahedron: Asymmetry 2010, 21, 688-694. doi:10.1016/j.tetasy.2010.04.019

38. Al'fonsov, V. A.; Andreeva, O. V.; Bakaleinik, G. A.; Beskrovnyi, D. V.; Gubaidullin, A. T.; Kataev, V. E.; Kovylyaeva, G. I.; Konovalov, A. I.; Korochkina, M. G.; Litvinov, I. A.; Militsina, O. I.; Strobykina, I. Yu. Russ. J. Gen. Chem. 2003, 73, 1255-1260. doi:10.1023/B:RUGC.0000007651.53262.a5

39. Andreeva, O. V.; Garifullin, B. F.; Gubaidullin, A. T.; Al'fonsov, V. A.; Kataev, V. E.; Ryzhikov, D. V. J. Struct. Chem. 2007, 48, 540-546. doi:10.1007/s10947-007-0081-1

40. Bomkamp, M.; Artiukhov, A.; Kataeva, O.; Waldvogel, S. R. Synthesis 2007, 1107-1114. doi:10.1055/s-2007-965986

41. Swager, T. M. Acc. Chem. Res. 2008, 41, 1181-1189. doi:10.1021/ar800107v

42. Zhang, C.; Liu, Y.; Li, B.; Tan, B.; Chen, C.-F.; Xu, H.-B.; Yang, X.-L. ACS Macro Lett. 2012, 1, 190-193. doi:10.1021/mz200076c

43. Chong, J. H.; Ardakani, S. J.; Smith, K. J.; MacLachlan, M. J. Chem.-Eur. J. 2009, 15, 11824-11828. doi:10.1002/chem.200902188

44. McKeown, N. B.; Budd, P. M.; Book, D. Macromol. Rapid Commun. 2007, 28, 995-1002. doi:10.1002/marc.200700054

45. Mastalerz, M.; Oppel, I. M. Angew. Chem. 2012, 124, 5345-5348. doi:10.1002/ange.201201174

Angew. Chem., Int. Ed. 2012, 51, 5252-5255. doi:10.1002/anie.201201174

46. Zhao, Y.-C.; Cheng, Q.-Y.; Zhou, D.; Wang, T.; Han, B.-H. J. Mater. Chem. 2012, 22, 11509-11514. doi:10.1039/c2jm31187a

47. Hashem, M.; Grazia Bezzu, C.; Kariuki, B. M.; McKeown, N. B. Polym. Chem. 2011, 2, 2190-2192. doi:10.1039/c1py00288k

48. Ghanem, B. S. Polym. Chem. 2012, 3, 96-98. doi:10.1039/c1py00423a

49. Schneider, M. W.; Oppel, I. M.; Ott, H.; Lechner, L. G.; Hauswald, H.-J. S.; Stoll, R.; Mastalerz, M. Chem.-Eur. J. 2012, 18, 836-847. doi:10.1002/chem.201102857

50. Rabbani, M. G.; Reich, T. E.; Kassab, R. M.; Jackson, K. T.; El-Kaderi, H. M. Chem. Commun. 2012, 48, 1141-1143. doi:10.1039/c2cc16986j

51. Tauchert, M. E.; Warth, D. C. M.; Braun, S. M.; Gruber, I.; Ziesak, A.; Rominger, F.; Hofmann, P. Organometallics 2011, 30, 2790-2809. doi:10.1021/om200164f

52. Li, Y.; Wilson, J. J.; Do, L. H.; Apfel, U.-P.; Lippard, S. J. Dalton Trans. 2012, 41, 9272-9275. doi:10.1039/c2dt31260c

53. Frantz, D. K.; Linden, A.; Baldridge, K. K.; Siegel, J. S. J. Am. Chem. Soc. 2012, 134, 1528-1535. doi:10.1021/ja2063346

54. Jacquot de Rouville, H.-P.; Garbage, R.; Cook, R. E.; Pujol, A. R.; Sirven, A. M.; Rapenne, G. Chem.-Eur. J. 2012, 18, 3023-3031. doi:10.1002/chem.201102893

55. Chong, J. H.; MacLachlan, M. J. Chem. Soc. Rev. 2009, 38, 3301-3315. doi:10.1039/b900754g

56. Jiang, Y.; Chen, C.-F. Eur. J. Org. Chem. 2011, 6377-6403. doi:10.1002/ejoc.201100684

57. Lubczyk, D.; Siering, C.; Lörgen, J.; Shifrina, Z. B.; Müllen, K.; Waldvogel, S. R. Sens. Actuators, B 2010, 143, 561-566. doi:10.1016/j.snb.2009.09.061

58. Fenn, J. B. Angew. Chem. 2003, 115, 3999-4024. doi:10.1002/ange.200300605 Angew. Chem., Int. Ed. 2003, 42, 3871-3894. doi:10.1002/anie.200300605
59. Rapp, M.; Bender, F.; Lubert, K.-H.; Voigt, A.; Bargon, J.; Wächter, L.; Klesper, G.; Klesper, H.; Fusshöller, G. Vorrichtung zum Aufbringen von Elektrospraybeschichtungen auf elektrisch nicht leitfähigen Oberflächen. Ger. Pat. 103,44,135 A1, May 4, 2005.

60. Martin, T.; Obst, U.; Rebek, J., Jr. Science 1998, 281, 1842-1845. doi:10.1126/science.281.5384.1842

61. Mastalerz, M.; Sieste, S.; Cenić, M.; Oppel, I. M. J. Org. Chem. 2011, 76, 6389-6393. doi:10.1021/jo200843v

62. Riley, H. L.; Morley, J. F.; Friend, N. A. C. J. Chem. Soc. 1932, 1875-1883. doi:10.1039/jr9320001875

63. Waitkins, G. R.; Clark, C. W. Chem. Rev. 1945, 36, 235-289. doi:10.1021/cr60115a001

64. Bomkamp, M.; Gottfried, K.; Kataeva, O.; Waldvogel, S. R. Synthesis 2008, 1443-1447. doi:10.1055/s-2008-1072533

65. Coates, R. M.; Kang, H. Y. J. Org. Chem. 1987, 52, 2065-2074. doi:10.1021/jo00386a031

66. Kovylyaeva, G. I.; Sharipova, R. R.; Strobykina, I. Yu.; Militsina, O. I.; Musin, R. Z.; Beskrovnyi, D. V.; Gubaidullin, A. T.; Al'fonsov, V. A.; Kataev, V. E. Russ. J. Gen. Chem. 2009, 79, 2663-2667. doi:10.1134/S1070363209120184

67. Hiroaki, S. H. M. Process for synthesizing cyclic peptide compound. Eur. Pat. 2,141,175 A1, March 26, 2010.

68. Merski, M.; Townsend, C. A. J. Am. Chem. Soc. 2007, 129, 15750-15751. doi:10.1021/ja076704r

69. Misner, J. W.; Fisher, J. W.; Gardner, J. P.; Pedersen, S. W.; Trinkle, K. L.; Jackson, B. G.; Zhang, T. Y. Tetrahedron Lett. 2003, 44, 5991-5993. doi:10.1016/S0040-4039(03)01483-7

70. Muthusamy, S.; Gnanaprakasam, B.; Suresh, E. J. Org. Chem. 2007, 72, 1495-1498. doi:10.1021/jo062043p

71. Brutschy, M.; Schneider, M. W.; Mastalerz, M.; Waldvogel, S. R. Adv. Mater. 2012, 24, 6049-6052. doi:10.1002/adma.201202786

72. Brutschy, M.; Schneider, M. W.; Mastalerz, M.; Waldvogel, S. R. Chem. Commun. 2013, 49, 8398-8400. doi:10.1039/c3cc43829e

\section{License and Terms}

This is an Open Access article under the terms of the Creative Commons Attribution License (http://creativecommons.org/licenses/by/2.0), which permits unrestricted use, distribution, and reproduction in any medium, provided the original work is properly cited.

The license is subject to the Beilstein Journal of Organic Chemistry terms and conditions:

(http://www.beilstein-journals.org/bjoc)

The definitive version of this article is the electronic one which can be found at: $\underline{\text { doi:10.3762/bjoc. } 9.317}$ 